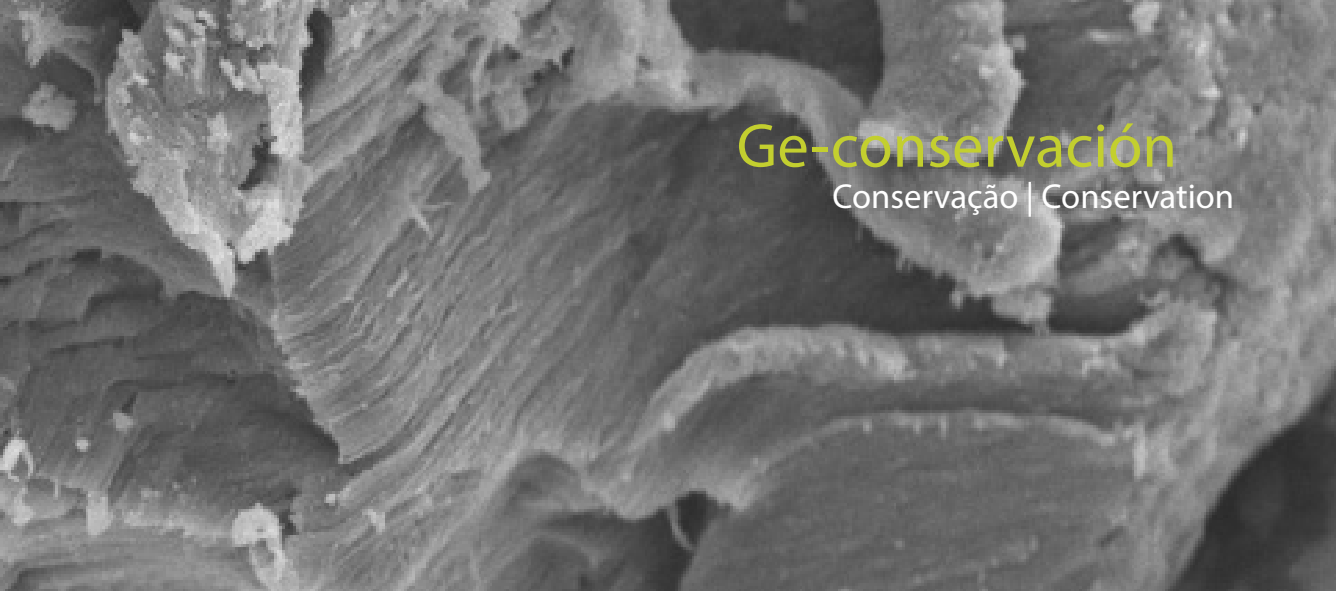

\title{
Survey of the state of conservation of the Mylodon listai (Xenarthra-Mylodontidae) skin fragment from the Pleistocene of Argentina kept at the Museum of La Plata (Argentina)
}

\author{
Daniela Silvana Nitiu, Andrea Mallo, Mario Saparrat, Mauro Garcia Santa Cruz
}

\begin{abstract}
The aim of the present study was to assess the state of conservation of the fossilized skin fragment assigned to Mylodon listai preserved in a showcase of the Paleontology Hall of the Museum of La Plata. To this end, we conducted a volumetric aerobiological sampling both inside the showcase and in the hall to detect the presence of fungal load that could alter its preservation. We also determined the environmental parameters both inside and outside the showcase. The aerobiological sampling inside the showcase showed 3061.50 spores $/ \mathrm{m} 3$ corresponding to 22 fungal types, while in the hall, 2283.20 spores $/ \mathrm{m} 3$ corresponding to 14 fungal types where detected. Cladosporium was the most important type in all the sampling points. The temperatures recorded were lower than those recommended for the conservation of leather and the relative humidity values were acceptable in $70 \%$ of the record for this material
\end{abstract}

Keyword: environmental monitoring, fungal load, preventive conservation, Mylodon listai, Museum of La Plata

\section{Estudio del estado de conservación del fragmento de piel de Mylodon listai (Xenarthra- Mylodontidae) del Pleistoceno argentino conservado en el Museo de La Plata (Argentina)}

Resumen: El objetivo del presente trabajo fue evaluar el estado de conservación de un fragmento fósil de cuero de Mylodon listai conservado en una vitrina de la Sala de Paleontología del Museo de La Plata. Se realizó un muestreo aerobiológico volumétrico en el interior de la vitrina y en la Sala con el objeto de detectar la presencia de carga fúngica que pudiera alterar su preservación. Se relevaron parámetros ambientales en el interior y exterior de la vitrina. El muestreo aerobiológico reveló en el interior del expositor un total de 3061.50 esporas $/ \mathrm{m} 3$ y 22 tipos fúngicos mientras que en la sala se cuantificó un total de 2283.20 esporas/m3 y 14 tipos fúngicos. Cladosporium sp. fue el máximo exponente identificándose en todos los puntos del muestreo. Las temperaturas registradas en la vitrina son menores a las recomendadas y la humedad relativa es aceptable en un $70 \%$ del registro para la conservación de cuero.

Palabras clave: monitoreo ambiental, carga fúngica, conservación preventiva, Milodon listai, Museo La Plata.

\section{Estudo do estado de conservação do fragmento de pele de Mylodon Listai (Xenarthra- Mylodontidae) do Pleistoceno argentino conservado no Museu da Plata (Argentina)}

Resumo: O objetivo deste estudo foi avaliar o estado de conservação de um fragmento fóssil de couro de Mylodon listai conservado numa vitrina na sala de Paleontologia do Museu da Plata. Levou -se a cabo uma recolha de amostras aerobiológicas volumétrico no interior da vitrina e na sala com o objetivo de detetar a presença de carga fúngica que pudesse ter alterado a sua conservação. Encontraram-se parâmetros ambientais no interior e no exterior da vitrina. A recolha de amostras revelou que no interior do expositor havia um total de 3061.20 esporos de fungos / m3 e 22 tipos de fungos enquanto que na sala quantificaram-se um total de 2283.20 esporos de fungos / $\mathrm{m} 3$ e 14 tipos de fungos. O Cladosporium sp. Foi o máximo expoente identificado em todos os pontos da recolha de amostras. As temperaturas registadas na vitrina são menores às recomendadas e a humidade relativa é aceitável em $70 \%$ do registo para a conservação do couro.

Palavras-chave: monitoramento ambiental, carga fúngica, Conservação preventiva, Mylodon listai, Museu de La Plata 


\section{Introducción}

The collections of the Division of Vertebrate Paleontology at the Museum of Natural Sciences of La Plata (La Plata, Buenos Aires, Argentina) host more than 120.000 specimens from cataloged fossil vertebrates. These scientific collections have more than 500 type specimens and 2300 figured specimens (www.museo.fcnym.unlp.edu.ar). These collections, many of which were obtained by reference naturalists as F.P. Moreno, F. and C. Ameghino, R. Hauthal, A. Mercerat and S. Roth, among others, in the second half of the nineteenth and early twentieth centuries, testify the past 250 million years of evolution in the extreme south of the American continent. In the last decades, other important collections due to their variety or number of specimens have been added to these collections.

The Museum of La Plata has on display a Mylodon listai skin fragment and remnants of fecal matter that were found by the German soldier Hermann Eberhardt in 1895 in the Cave "Última Esperanza"located in the Magallanes province in the Austral Patagonia of Chile. In 1897, such site was visited by Francisco P. Moreno, who took the skin fragment to London, England, for its study in 1898. A fragment of this skin was then taken to the Museum of La Plata in Argentina (Moreno \& Woodward, 1899; Martinic, 1996). The material found lacked the head and extremities. Its skin was very hard, about 10$15 \mathrm{~mm}$ thick, composed of bony plates called osteoderms and thick $3-5-\mathrm{cm}$-long blond hairs. Carbon-14 studies carried out in the Laboratory of Tritium and Radiocarbon of the Museum of La Plata allowed assigning the material an average age of 11-12 thousand years, which corresponds to the end of the Pleistocene (Tonni et al., 2003).

Mylodon listai (Xenarthra-Mylodontinae) was a large quadruped herbivorous belonging to the same group as current armadillos, anteaters and sloths, with the ability to stand in two legs. It was $1.50 \mathrm{~m}$ tall $\times 75 \mathrm{~cm}$ wide and it could weigh one ton. From the taxonomic point of view, researchers have not reached a consensus about the number of valid taxa for the genus Mylodon (Kraglievich, 1934; Esteban, 1996; Tonni et al., 2003). The following species have been included in it: Mylodon darwini Owen and Mylodon insigne Kraglievich, from the Pampean region, and Mylodon listai Ameghino, from the Argentine Patagonian region and similar regions in Chile (Brandoni et al., 2010).

The Museum of La Plata conserves objects and material which form part of the material memory of our ancestors, and plays a vital cultural and educational role for the whole country. Thus, a good state of conservation of both its building structure and the environmental context where the collections are hosted is vital to keep the material in good condition and minimize natural progressive ageing. Records of relative humidity, temperature, light intensity, light quality, and pest control, as well as of the conditions of exposure, storage, maintenance (cleaning, periodic controls), and handling of the material should be a priority.
Although there is no consensus on the range of temperature and relative humidity required to conserve collections, each specimen or part has specific requirements which are dependent on their composition and state of preservation. Also, intradiurnal fluctuations of temperature and relative humidity play a preponderant role in preservation. If these fluctuations are significant, they may constitute a major problem because they may promote stress that can damage the specimen, sometimes being irreversible (Michalski, 2007). The aim of the present study was to assess the state of conservation of the skin fragment assigned to Mylodon listai displayed in a showcase located in the Vertebrate Paleontology Hall of the Museum of La Plata, and monitor the fungal spore load and environmental conditions associated with this hall.

\section{Materials and methods}

\section{Study site}

The Exhibition Hall of Paleontology of Cenozoic Vertebrates of the Museum of Natural Sciences of La Plata that hosts the Mylodon listai skin fragment studied in the present work is located on the ground floor. This hall has an area of approximately $70 \mathrm{~m} 2$ and is connected to other immediate Paleontology Halls, which host fossils of other geological ages. The walls of this hall are covered by 20 closed showcases that host various fossils. The center of the room displays a reconstruction of the life in the past based on large mammal fossils ("megafauna"), remains which have been preserved from the organisms, and signs of their activity [figure 1.1]. Room lighting in the hall is natural through windows, whereas that inside the showcases is artificial.

The showcase of the genus Mylodon is $1.30 \mathrm{~m}$ high, $1.50 \mathrm{~m}$ wide and $0.55 \mathrm{~m}$ deep, is built in wood and glass, and has a constant warm fluorescent lighting during the opening hours of the Museum. In addition to the biological remains, there are two explanatory posters of the site of discovery, characterization of Mylodon and the geographic location of the cave "Última Esperanza" in the Austral Patagonia of Chile [figure 1.2].

\section{Sampling}

\section{Collection of aerobiological samples}

Air samples from both the Exhibition Hall and the inside of the showcase were collected through a volumetric system, which consists in taking air samples with a Z-LitelAQ vacuum pump calibrated at $15 \mathrm{l} / \mathrm{m}$, connected to a disposable Air or Cell ${ }^{\oplus}$ cassette. Each sample was the result of the air particles captured during the passage of air through the cassette for 5 minutes. We followed a diagonal sampling design, taking three reference points (upper, middle and lower sectors), both within the hall and inside the showcase, according to the FEDECAI-01 standards (2007). 

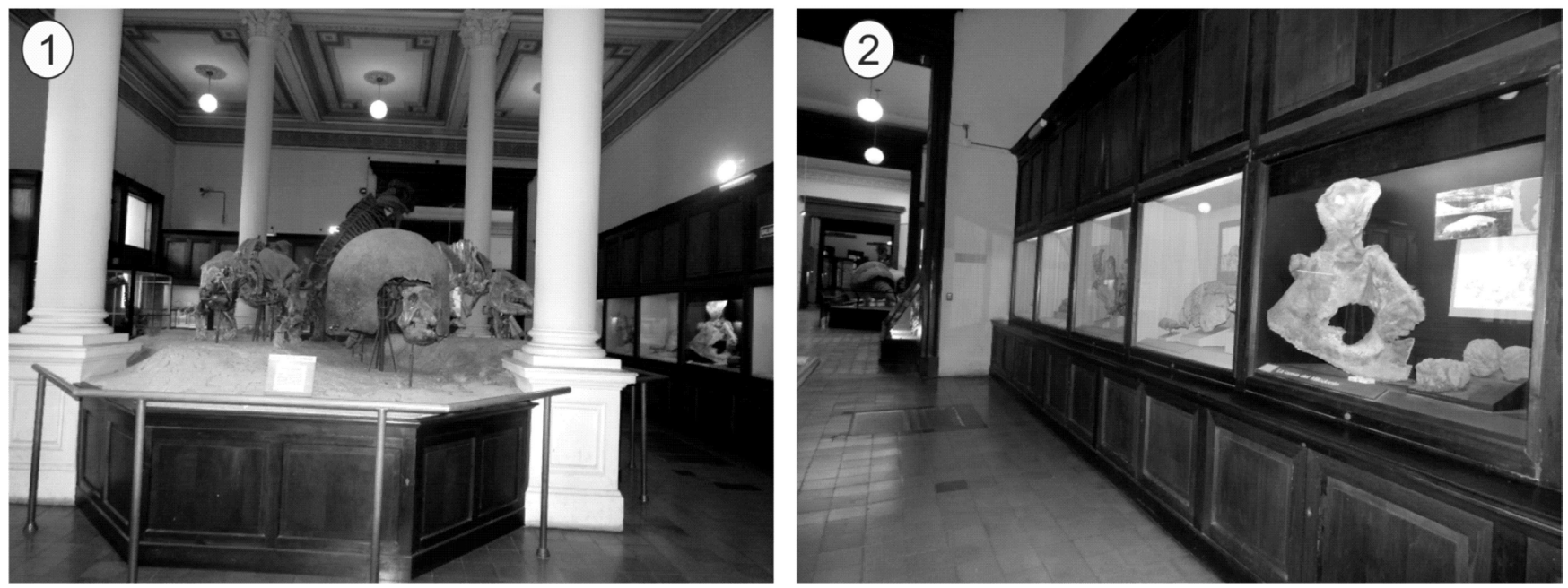

Figure 1.- Hall of Paleontology of Pleistocene Vertebrates of the Museum of La Plata, La Plata. 2, Showcase where the skin fragment of Mylodon listai is kept.

Each cassette sample obtained was processed using the Air or Cell ${ }^{\circledR}$ protocol, mounted, and stained with lactophenol cotton blue for its analysis. Samples were observed with an optical magnification of $400 \mathrm{X}$, covering $100 \%$ of the sampled surface. Bioaerosols, particularly fungal spores, were identified using reference atlases (Käärik et al., 1983; Barnet and Hunter, 1987; Grant Smith 1990; Lacey and West, 2006; Nitiu et al., 2010) and specialized databases. The concentration of each air particle/m3 was estimated following Baxter's procedure (2006).

Characterization of the skin, isolated fossil hairs and coprolite

The skin was macroscopically observed with binocular lenses $4.8 \mathrm{X}$ to characterize it and distinguish possible fungal structures on its surface. The isolated fossil hairs available at the base of the showcase were processed according to the technique of Arita and Aranda (1987) and characterized with an optical microscope. On the other hand, the material destined for scanning electron microscope was processed following the protocol of Bozzola and Russel (1991). Photomicrographs were obtained from both techniques. With respect to the coprolite, we followed the direct contact technique, according to the protocol previously described (Nitiu et al., 2015).

\section{Analysis of temperature and relative humidity}

The HOBO Temp/RH data logger records temperature and relative humidity (within $2.5 \%$ accuracy) in indoor environments with its integrated sensors. The device was placed inside the showcase and two similar data loggers were placed in the Paleontology Hall to record the values of temperature and relative humidity in both sectors. These values were then analyzed by means of graphs and tables.

\section{Results}

To obtain an atmosphere as stable as possible in terms of microorganisms and physical variables, the sampling was carried out on September 30th, 2015, between 8 and 10 o'clock a.m., a lapse in which the Museum is still closed to the public. The relative humidity and temperature of the hall during the sampling period were $59 \%$ and $15^{\circ} \mathrm{C}$ respectively, whereas those inside the showcase were $57 \%$ and $16^{\circ} \mathrm{C}$ respectively.

\section{Aerobiological study}

The aerobiological analysis inside the showcase allowed quantifying a total of 3061.50 spores/m3, corresponding in the three sampling points to a mycobiota represented by 22 fungal types. In the lower and middle sectors of the showcase, the fungal load did not exceed 800 propagules/ m3, with only 10 morphological types in each sector, whereas the upper sector revealed greater concentration and richness of fungal taxa [table 1].

Fungal taxa such as Cladosporium cladosporioides, Agrocybe sp., Coprinus sp. and Agaricus sp. were represented in the three sectors, with $C$. cladosporioides being the most abundant, with $76.09 \%, 39.29 \%$ and $39.81 \%$ in the upper, middle and lower sectors respectively.

The area outside the showcase (the hall) revealed a total of 2283.20 spores/m3 corresponding to 14 fungal types, with 639.98 spores/m3, 518.91 spores/m3 and 1107 spores/m3 contributed by 7,10 , and 11 morphological types in the upper, middle and lower sectors respectively. Spores of $C$. cladosporioides, Agrocybe sp., Agaricus sp., Coprinus sp., Leptosphaeria type, and Didimospora type were common to all sites. The lower sector was characterized by the Leptosphaeria type, with $23.68 \%$, whereas the middle and upper sectors were characterized by the presence of $C$. cladosporioides, with $40 \%$ and $42.19 \%$ respectively [table 2]. 


\begin{tabular}{lll}
\hline \multicolumn{2}{l}{ Fungal spore identified in the inside the showcase } & \\
\hline Lower sector & Middle sector & Upper sector \\
\hline Cladosporium cladosporioides & Cladosporium cladosporioides & Cladosporium cladosporioides \\
Coprinus & Agrocybe & Myxomycota \\
Agaricus & Agaricus & Aspergillus/Penicillium \\
Agrocybe & Myxomycota & Chaetomium \\
Chatomium & Tipo Lepthosphaeria & Boletus \\
Tipo Lepthosphaeria & Coprinus & Tipo Arthrinium \\
Ganoderma & Botrytis & Agrocybe \\
Tipo Didimosphaeria & Tipo Arthrinium & Politrincium \\
Alternaria & Tipo Caloplaca & Tipo Sporidesmium \\
Parapheosphaeria & Ganoderma & Parapheosphaeria \\
& & Coprinus \\
& & Agaricus \\
& Curvularia \\
& Cercospora \\
& Tipo Didimosphaeria \\
& & Diatrypaceae
\end{tabular}

Table 1.- Spores types identified at the three sampling heights (sectors) inside the showcase where the skin of Mylodon listai is kept

\begin{tabular}{|c|c|c|}
\hline \multicolumn{3}{|c|}{ Fungal spore identified in the Sala of Paleontologv } \\
\hline Lower sector & Middle sector & Upper sector \\
\hline $\begin{array}{l}\text { Tipo Lepthosphaeria } \\
\text { Tipo Didimella } \\
\text { Agaricus } \\
\text { Aspergillus/Penicillium } \\
\text { Cladosporium cladosporioides } \\
\text { Coprinus } \\
\text { Agrocybe }\end{array}$ & $\begin{array}{l}\text { Cladosporium cladosporioides } \\
\text { Agaricus } \\
\text { Tipo Lepthosphaeria } \\
\text { Tipo Didimella } \\
\text { Agrocybe } \\
\text { Myxomycota } \\
\text { Cercospora } \\
\text { Coprinus } \\
\text { Trichotecium } \\
\text { Ganoderma }\end{array}$ & $\begin{array}{l}\text { Cladosporium cladosporioides } \\
\text { Agaricus } \\
\text { Tipo Lepthosphaeria } \\
\text { Caloplaca } \\
\text { Tipo Didimella } \\
\text { Coprinus } \\
\text { Cladosporium herbarum } \\
\text { Agrocybe } \\
\text { Tipo Botritis } \\
\text { Tipo Cercospora } \\
\text { Tipo Didimosphaeria }\end{array}$ \\
\hline
\end{tabular}

Table 2.- Spores types identified at the three sampling heights (sectors) of the Paleontology Hall.

The air of the hall also presented skin flake-like organic fragments and other opaque particles associated with environmental dust (data not recorded).

Macroscopic naked-eye observations of the skin allowed recognizing an extremely hard skin, with light-yellow 3-5-cm-long hairs ending in a narrower blunt tip [figure $2.1,4]$ Although the diameter of the hair was uniform, the basal area was slightly narrower. The electron microscope showed a compact surface with waxy depositions vulnerable to treatment with xylol [figures 2.2, 5]. In addition, we observed cracks along the hair structure, which were possible signs of dehydration. We identified no fungal colonies, hyphae or propagules associated with the fur. Optical microscopy also revealed the absence of bone marrow [figures 2.3,6]. Direct observation of the contact samples of the coprolite allowed identifying no fungal hyphae or structures on the surface. 


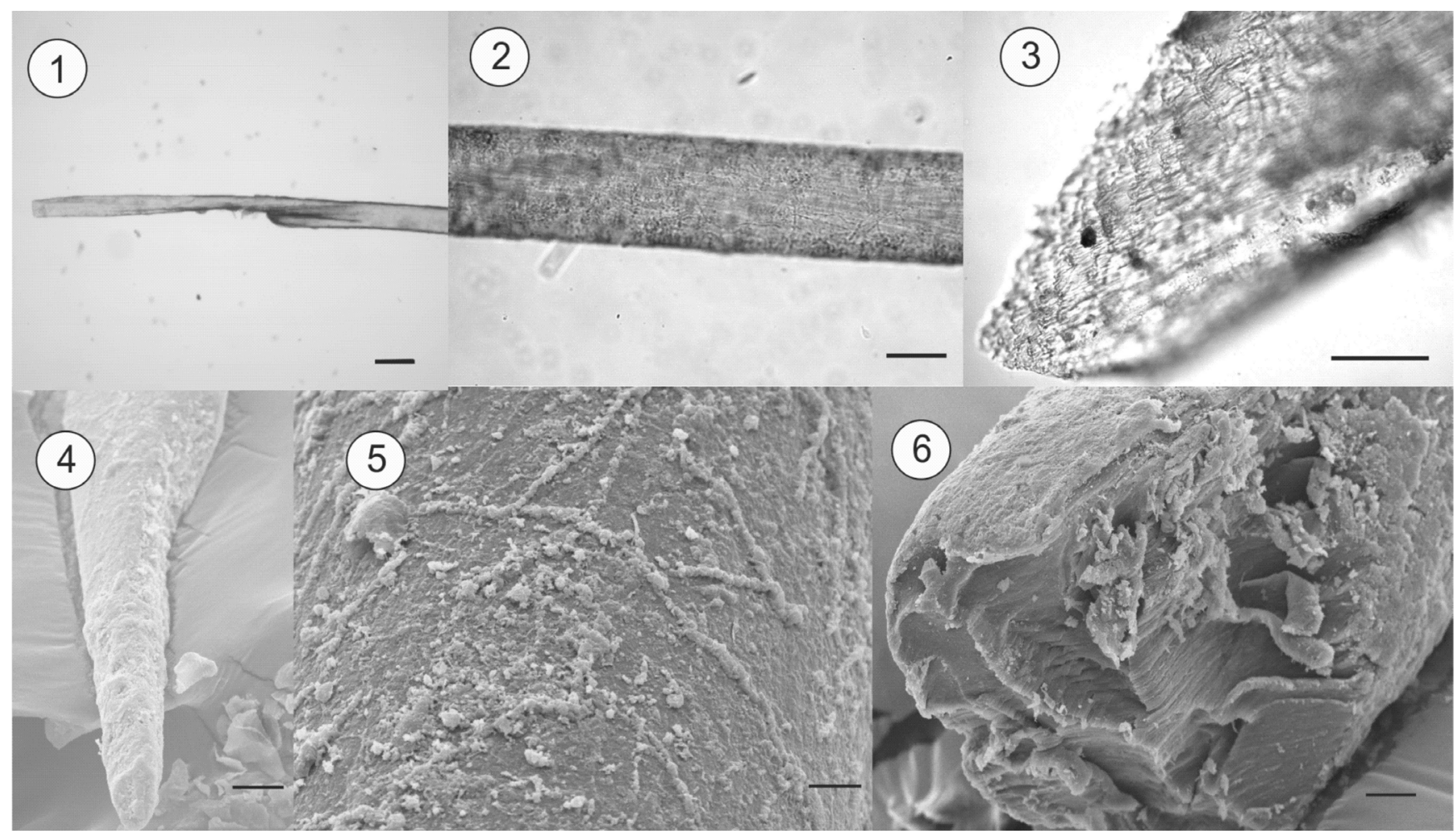

Figure 2.- Photomicrograph of fossil hair obtained by optical microscope (1-3) and by scanning electron microscope (4-6). 1, Detail of the blunt tip of the hair $(S c a l i n g=20 \mu \mathrm{m}) .2$, Detail of the hair surface. (Scaling $=10 \mu \mathrm{m}) .3$, Detail of the inner section of the hair where the absence of bone marrow is observed. (Scaling $=20 \mu \mathrm{m}) .4$, Detail of the blunt tip of the hair (Scaling $=200 \mu \mathrm{m}) .5$, Detail of the hair surface (Scaling $=100 \mu \mathrm{m}) .6$, Detail of the inner section of the hair where the absence of bone marrow is observed (Scaling $=200 \mu \mathrm{m})$.

\section{Discussion and conclusions}

The Vertebrate Paleontology Halls of the Museum of La Plata are home to important paleobiological collections that provide support to the historical information about the natural environment and evidence of primitive life (Brook et al. 2015). The Mylodon is a reference fossil of the late Pleistocene and early Holocene of the south of Argentina, of which scarce fractions are kept in the world. Thus, the skin fragment kept at this Museum is of great heritage value for the institution, and actions aimed at its preservation and long-term conservation are essential.

It is well known that the air inside each museum is characterized by the building materials, furniture and types of showcases used, but also by microclimatic parameters, ventilation systems and lighting of each hall or showcase, which, together with the different materials and textures that make up the cultural/patrimonial property, may contribute to the presence and growth of bioaerosols (Shelton et al., 2002). In addition, the anthropogenic activity can play a very important role either due to its involuntary action as a means of transport of particles or for being a potential substrate for the development of different fungal structures (Van Duin, 2014).

In the present study, the analysis of the mycological load of the environment of the Paleontology Hall and the inside of the showcase where the Mylodon skin fragment is displayed showed the presence of 22 morphological types, which contributed to a total of 1020.50 spores $/ \mathrm{m} 3$. On the other hand, the microbiology of the atmosphere of the hall was represented by 14 spore types, which contributed an average of $761.06 \mathrm{spores} / \mathrm{m}^{3}$. These differential values of richness and concentration between both sites could be due to the fact that the hall has wide connections with other adjacent areas where the atmosphere may be a key element as a means of transportation for particles, generating a cleaning effect and decreasing the concentration of particles, whereas the showcase is an enclosed space with low air current and possibility of removal (Borrego \& Perdomo 2014).

The analysis of spore richness and total concentration at the different heights of the hall and the showcase showed larger values in the upper sectors in both sites. This may indicate that the atmosphere in the upper sector is more stable or less disturbed by anthropogenic activity or by the environmental flow than that in the lower sector. These results are similar to those of Khattab and Levetin (2008) but different from those of Atluri et al., (1988) and RantioLethimaki et al., (1999), who reported lower concentrations of this spore type as the sampling height increases.

With respect to the other three spore types that were common to both sites, Agrocybe presented slightly greater concentrations in the upper sector of the showcase, Agaricus had a similar behavior in the hall, and Coprinus showed similar concentrations at the different sampling heights. 
Although we must consider each spore type in particular, several authors agree that small spores are commonly found at higher heights and large spores at lower heights (Khattab \& Levetin, 2008).

The fact that 11 of the spore types found were common to both sampling sites would indicate the existence of some kind of connection between sites, mainly by the lower sector of the showcase, where you have access to it. The spore types involved were mostly representatives of the Phyla Ascomycota, with the anamorphs AspergillusPenicillium sp., Botrytis sp., Cladosporium cladosporioides and Cercospora sp., and teleomorphs such as Leptosphaeria sp. and Caloplaca sp. We also identified Basidiomycota spores: Agaricus sp., Agrocybe sp., Coprinus sp. and Ganoderma $\mathrm{sp}$., as well as representatives morphologically related to Myxomycota (Phylum Mycetozoa). Cladosporium sp. was the most important spore type in the three sampling sectors of both sampling sites. Singh (2003), Florian (2004), Valentin (2010) and Solís (2011) reported Cladosporium sp. as one of the main pollutant genera of interior rooms at global level and as a spore type commonly isolated in homes, archives, libraries and museums (Walter, 2003; Gutarowska, 2010).

Our macroscopic and microscopic observations confirm the absence of bone marrow of the hair of the skin fragment of Mylodon listai, described by Ridewood in 1901 and mentioned by Arzani et al., (2014).

The development of microorganisms, including that of environmental fungi, stops when the activity of the support water is lower than that needed to remain in a resistance phase for a variable period of time (García Miniet \& Sánchez Espinosa, 2012). In the case of spores, the resistance phase can be extended for years, thus not being alarming for the development of biodeterioration (Florian, 2004).

Despite the presence of suspended spores, the absence of signs of deterioration both in the skin and hair is a clear sign of the good state of conservation of the Mylodon specimen hosted at the Museum of La Plata. However, the fall of the hairs from the skin continues to be a concern that needs to be clarified and controlled. In this sense, photochemical and hydrothermal stability processes (González Álvarez, 2005) or molecular strategies to obtain nucleic acids from fossilized dehydrated biological material may help determine the need to maximize the preservation of materials of biological collections.

The vegetative state of fungi, either as unicellular fungi or in the form of mycelia, is a key physiological state in the process of degradation of various media used as growing substrates (Guiamet et al., 2006; Cappitelli \& Sorlini, 2010; Rodriguez García 2016). Under appropriate temperature and relative humidity conditions, the mycobiota can latently coexist with museum specimens in the state of spores. However, an increase in temperature and relative humidity can lead to the activation of the propagules as well as to their germination and mycelial development, generating serious problems in the biodeterioration of specimens (Pinzari et al., 2004).

Considering that the specimen studied was a skin fragment, we determined the reference values recommended for the conservation of the category "skin" (UNI10829:1999 Norm), which considers optimal values of relative humidity those between $45 \%$ and $60 \%$ and optimal values of temperature those between $19^{\circ} \mathrm{C}$ and $24^{\circ} \mathrm{C}$. In our study, the temperatures recorded by the data loggers at both sites were lower than the recommended ones. However, we must consider that the sampling was carried out in winter and that these values are thus acceptable. Analysis of the histogram of temperature and relative humidity showed that the temperature in the hall behaved similarly to that inside the showcase and that the values of relative humidity showed greater dispersion [figure 3].

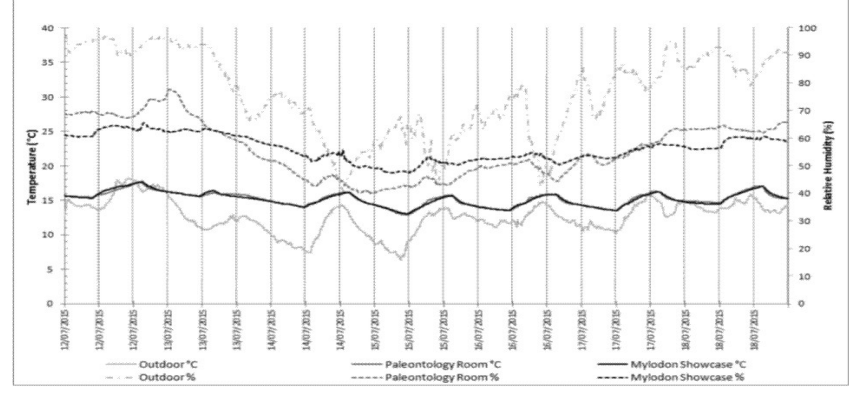

Figure 3.- Histogram of the temperature and relative humidity of the Paleontology Hall and of the inside of the Mylodon showcase, obtained between July $12^{\text {th }} 2015$ and July $18^{\text {th }} 2015$.

On the other hand, the daily variation of temperature recorded by the data loggers was higher than the recommended one and the daily variation of relative humidity in the showcase was optimal in six of the seven days analyzed, although that in the hall was higher than the recommended one in half of the days [figure 4]. In addition, $42 \%$ of the relative humidity values recorded in the hall and $70 \%$ of the values recorded inside the showcase were within those recommended for the conservation of skin.

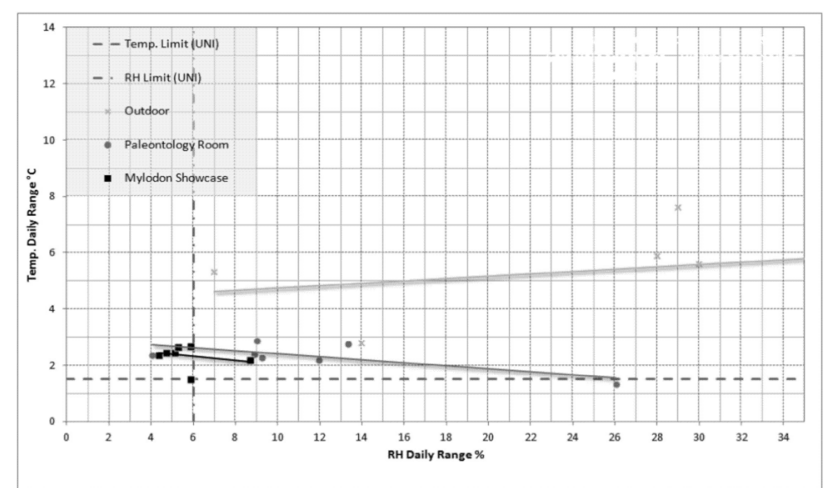

Figure 4.- Variation in the daily temperature and relative humidity of the Paleontology Hall and the Mylodon showcase. Relative humidity and temperature limits for the preservation of skin. 
Although most of the fungal types identified are representatives of ubiquitous indoor genera, the presence of Aspergillus/Penicillium and Cladosporium alerts on the need to carry out a continuous scrutiny given their significance as environmental contaminants (Hyvärinen, 2001; Xu \& Yao, 2011).

Given the historical importance of the skin fragment of Mylodon as well as that of other related specimens for the Paleontology of the South American region, the early detection of biological or physical agents with possible negative action is essential to minimize the natural progressive ageing and avoid potential problems and losses by biodeterioration that may impact on the patrimonial history of such region.

\section{Acknowledgments}

The present study was financially supported by the Consejo Nacional de Investigaciones Científicas y Técnicas (CONICET) PIP 112-201101-00087, PIP 112-20110100391; Agencia Foncyt PICT 2013-0418, and Proyecto de Incentivos a la Investigación (N11/781) of the Facultad de Ciencias Naturales y Museo (FCNyM), Argentina. We thank the Paleontology Unit of the FCNyM and the Conservation and Exhibition Unit of the Museum of La Plata. We also thank Dr. Lorena Elíades for her collaboration and Dr. Marta Morbelli for her support.

\section{References}

ARITA, H. \& ARANDA, M. (1987). Técnicas para el estudio y clasificación de los pelos. Cuadernos de Divulgación, Instituto Nacional de Investigaciones sobre Recursos Bióticos; 32:1-21.

ARZANI, H., LANZELOTTI, S.L., ACUÑA SUÁREZ, G.E. \& NOVO, N.M. (2014). Primer registro de pelos fósiles en Glossotherium robustum (Xenarthra, Mylodontidae), Pleistoceno Tardío, Mercedes, Provincia de Buenos Aires. Ameghiniana; 51 (6): 585-590.

ATLURI, J., VERMA, K.V. \& REDDI, C.S. (1988). Distribution of fungal spore within and above a crop of rice. Proc. Indian Acad. Sci.; 98:25-30.

BARNET, H.L. \& HUNTER, B.B. (1987). Illustrated Genera of Imperfect Fungi, MacMillan Publ. Co. New York.

BAXTER, A. (2006). "Air O Cell Interpretation guide." Environmental Analysis Association. http://eaabaxter.com/ [last update 12/7/2016.].

BORREGO, S. \& PERDOMO, I. (2014). Caracterización de la micobiota aérea en dos depósitos del Archivo Nacional de la República de Cuba. Rev Iberoam Micol.; 31:182-187.

BOZZOLA, J.J. \& RUSSELL, L.D. (1991). Electron microscopy: principles and techniques for biologists. Jones and Barlett publishers. USA.
BRANDONI, D., FERRERO, B. \& BRUNETTO, E. (2010). Mylodon darwini Owen (Xenarthra, Mylodontinae) from the late Pleistocene of Mesopotamia, Argentina, with remarks on individual variability, paleobiology, paleobiogeography and paleoenvironment. Journal of Vertebrate Paleontology; 30:1547155.

BROOK, G.A, FRANCO, N.V., AMBRÚSTOLO, P., MANCINI, M.V., WANG, L. \& FERNANDEZ, P.M.(2015). Evidence of the earliest humans in the Southern Deseado Massif (Patagonia, Argentina), Mylodontidae, and changes in water availability. Quaternary International; 379:107-123.

CAPPITELLI, F. \& SORLINI, C. (2010). Paper and manuscripts. En Mitchell R. McNamara Cl. Editores. Cultural Heritage microbiology: Studies in conservation science. Washington. DC: ASM Press. 45-58.

ESTEBAN, G.I. (1996). Revisión de los Mylodontinae cuaternarios (Edentata-Tardigrada) de Argentina, Bolivia y Uruguay. Sistemática, filogenia, paleobiología, paleozoogeografía y paleoecología.Ph.D. dissertation, Universidad Nacional de Tucumán, Facultad de Ciencias Naturales e Instituto Miguel Lillo, Tucumán, 314 pp.

FEDECAI-01 2007 Programa de certificación de calidad ambiental en interiores. Calidad ambiental en interiores: Criterios de muestreo: 4-6. Federación Española de Empresas de Calidad Ambiental Interior (FEDECAI).

FLORIAN, M.L.E. (2004). Fungal facts. Solving fungal problem in heritage collections. London UK.

GARCÍA MINIET, M. \& SÁNCHEZ ESPINOSA, R. (2012). Estudio de la concentración fúngica aérea de los depósitos del Archivo Municipal de Cárdenas, Cuba. Revista de la Sociedad Venezolana de Microbiología; 32:37-43.

GUIAMET, P.S., GOMEZ DE SARAVIA, S.G., ARENAS, P., PEREZ, M.L., DE LA PAZ, J. \& BORREGO, S.F. (2006). Natural products isolated from plant used in biodeterioration control. Pharmacologyonline; 3:537-544.

GONZALEZ ALVAREZ, G. (2005). Recientes avances en conservación de objetos de cuero. [IsBasedOn] Museos.es: Revista de la Subdirección General de Museos Estatales; 1:8087.

GRANT SMITH, E. (1990). Sampling and identifying allergenic pollens and molds. Blewstone Press, San Antonio, Texas.

GUTAROWSKA, B. (2010). Metabolic activity of moulds as a factor of building materials biodegradation. Polish J. Microbiol.; 59:119-124.

HYVÄRINEN, A., VAHTERISTO, M., MEKLIN, T., JANTUNEN, M., NEVALAINEN, A. \& MOSCHANDREAS, D. (2001). Temporal and spatial variation of fungal concentrations. Indoor Air, Aerosol Science Technology; 35:688-695. 
KÄÄRIK, A., KELLER, J., KIFFER, E., PERREAU, J. \& REISINGER, O. (1983). In Nilsson, S. Ed. Atlas of airborne fungal spores in Europe. Springer -Verlag, Berlin.

KHATTAB, A. \& LEVETIN, E. (2008). Efect of sampling height on the concentration of airborne fungal spore. Annals of Allergy, Asthma \& Immunology 101:529-534.

KRAGLIEVICH, L. (1934). Contribución al conocimiento de Mylodon darwini Owen y especies afines. Revista del Museo de La Plata; 34:255-292.

LACEY, M.E. \& WEST, J.S. (2006).The Air Spore, Springer, Dordrecht, Netherlands.

MARTINIC, M. (1996). La cueva del Mylodon: Historia de los hallazgos y otros sucesos. Relación de los estudios realizados a lo largo de un siglo (1895-1995). Anales del Instituto de la Patagonia. Serie Ciencias Humanas:24.

MICHALSKI, S. (2007). Preservación de las colecciones. In Como administrar un Museo: Manual Práctico. UNESCO. 5190.

MORENO, F. \& WOODWARD, S.A. (1899). On a portion of mammalian skin, named Neomylodon listai, from a Cavern near Consuelo Cove, Patagonia. Proceedengs of the Zoological Society of London; 144-156.

NITIU D.S., MALLO A.C., ELÍADES L.A., SAPARRAT M.E. \& VAZQUEZ, H.R. (2015). Monitoreo de la carga fúngica ambiental y de otros bioaerosoles en un depósito de restos momificados del NOA del Museo de La Plata (Argentina). Boletín de la Sociedad Argentina de Botánica; 50(4):427-436.

NITIU, D.S., MALLO, A.C., GARDELLA SAMBETH, M.C. \& MORBELLI, M.A. (2010). Contribución a la identificación de esporas del Reino Fungi en la atmósfera de La Plata (Argentina). Boletín de la Sociedad Argentina de Botánica; 45:301-308.

NORMA UNI 10829:1999. Beni di interesse storico e artistico: Condizioni ambientali di conservazione mizurazione ed analisi. Ente Nazionale di Unificazione, Milano.

PINZARI, F., FANELLI, C., CANHOTO, O. \& MAGAN, N. (2004). Electronic nose for the early detection of moulds in libraries and archives. Indoor Built Environment; 13:387395.

RANTIO-LEHTIMAKI A., KOIVIKKO A., KUPIAS R., MAKINEN Y. \& POHJOLA A. (1991). Significance of sampling height of airborne particles for aerobiological information. Allergy; 46:68-76.

RIDEWOOD, W.G. (1901). On the structure of the hair of Mylodon listai and other South American edentate. Quarterly Journal of Microscopical Science; 2:393-411.
RODRIGUEZ GARCÍA, J.C. (2016). Evaluación aeromicrobiológica del depósito del Centro de Documentación del Museo Nacional de la Música de Cuba. Ge-conservacion 9; 117-126

SHELTON, B.G., KIRLAND, K.H., FLANDER W.D. \& MORRIS, G.K. (2002). Profiles of airborne fungi in building and outdoor environments in the United States. Applied an Environmental Microbiology; 68(4):1743-1753.

SINGH, J. (2003). European Heritage conservation and environmental monitoring-making informed decisions. European Heritage conservation environmentally sustainable Solutions. Dublin, Ireland, Trinity College.

SOLIS, E. (2011). Estudio micológico del aire en áreas ocupacionales y exteriores del laboratorio de investigación en productos naturales ubicado en el edificio T-10 en la ciudad universitaria en zona 12 y el laboratorio ubicado en la zona 1 del centro de información y asesoría toxicológica del departamento de toxicología de la facultad de ciencias químicas farmacia de la universidad de San Carlos de Guatemala.Web page: biblioteca.usac.edu.gt/ tesis/06/06_3102.pdf. [Last update 12/7/2016].

TONNI, E.P., CARLINI, A.A., SCILLATO YANÉ, G.J. \& FIGINI, A.J. (2003). Cronología radiocarbónica y condiciones climáticas en la "Cueva del Milodón" (sur de Chile) durante el Pleistoceno Tardío. Ameghiniana 40(4):609-615.

VALENTÍN, N. (2010). Microorganism in museum collections. Coalition; 19:2-5.

VAN DUIN, P. (2014). Climate effects on Museum objets. The Need for Monitoring and Analysis. In Conservation Perspective. The GCl Newsletter. Collection Environments; 29(2):13-16.

WALTER, A. (2003). Basic preservation guidelines for library and archive collections. London: Natural Preservation Office, NPO Preservation Guidance. British Library.

XU Z. \& YAO M. (2011). Analysis of culturable bacterial and fungal aerosol diversity obtained using different samplers and culturing methods. Aerosol Science Technology; 45:11431153. 


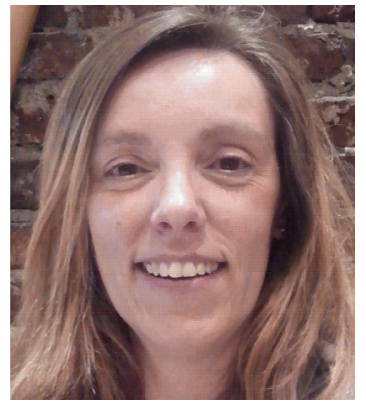

\title{
Dra. Daniela Silvana Nitiu
}

danielanitiu@yahoo.com.ar

Universidad Nacional de La Plata. Buenos Aires, Argentina

La Dra. Daniela S. Nitiu es docente en la Facultad de Ciencias Naturales y Museo desde 1996, fue becaria de CIC y CONICET. Obtuvo su título de Doctora en Ciencias Naturales con el tema "Estudio aeropalinológico de la ciudad de La Plata" en el año 2006, otorgado por la Facultad de Ciencias Naturales y Museo UNLP. Investigadora Asistente del CONICET desde 2009. Es Investigador Responsable de: un Proyecto PIP CONICET, un PICT y de un Proyecto de Incentivos a la Investigación de la UNLP. Categoría de Docente Investigador III. Evaluador de Proyectos de Investigación para CONICET, AGENCIA y UNLP y ha realizado arbitrajes en revistas internacionales. Es Directora de Tesis Doctoral de la Lic. Anabel Calderón (CONICET) desde 2015 y Directora de la pasante Lic Cintia San Martín en el Programa de Entrenamiento y Apoyo a la Investigación para estudiantes de la FCNYM (UNLP). Posee numerosos antecedentes en Reuniones y Publicaciones en distintos ámbitos científicos nacionales e internacionales. Ha recibido premios a trabajos científicos en diversos eventos científicos. Ha dictado un curso de Postgrado dentro del Programa INTER-U como Miembro Responsable en la Facultad de Química, Bioquímica y Farmacia. Universidad Nacional de San Luis (2012). Es miembro editor de la Revista Timisoara (Polonia). Trabaja en estudios aeromicológicos en ambientes de interior desde el año 2010.

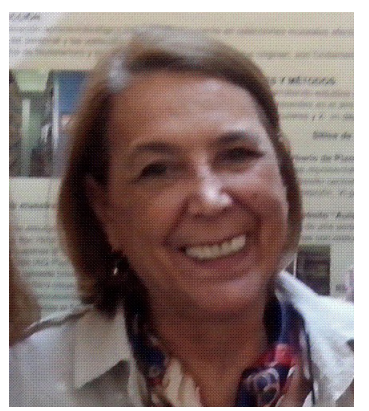

\author{
Lic. Andrea Cecilia Mallo \\ malloa2001@yahoo.com.ar \\ Universidad Nacional de La Plata. Buenos Aires, Argentina
}

La Lic. Andrea C. Mallo, se desempeña como Personal de Apoyo a la investigación, categoría Principal CIC -PBA en la temática de Aerobiología y Aeromicología desde el año 2006 en la Cátedra de Palinología de la Facultad de Ciencias Naturales y Museo. Docente en la Cátedra de Introducción a la Botánica en la Facultad de Cs Naturales y Museo, Categoría de Docente Investigador IV. Ha participado en 9 Proyectos de Investigación de la Universidad Nacional de la Plata y CONICET y en la actualidad es integrante de 2 Proyectos PIP CONICET y ANPCyT bajo la dirección de la Dra. Daniela Nitiu. Ha sido Miembro de Comisiones Asesoras, Consejo Consultivo Departamental de Botánica, evaluador de Proyectos de Investigación para la Agencia Nacional de Promoción Científica y Tecnológica (ANPCyT) y ha realizado arbitrajes en revistas internacionales. Actualmente posee 16 trabajos publicados en revistas científicas indexadas, 1 capítulo de libro, 5 trabajos completos en Actas de Congreso y 50 presentaciones en congresos en modalidad oral y paneles. Ha realizado informes técnicos de distintas Salas del Museo de La Plata y del Archivo y Biblioteca Ataúlfo Perez Aznar del Senado de la Provincia de Buenos Aires, Legislatura de la Provincia de Buenos Aires. Es Codirectora de una Pasantía en la Facultad de Ciencias Naturales y Museo. 


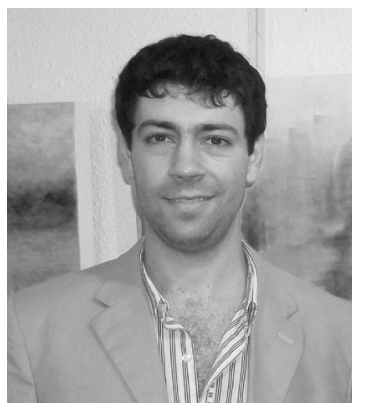

\author{
Arq. Mauro García Santa Cruz \\ mggarciasc@gmail.com \\ Universidad Nacional de La Plata. Buenos Aires, Argentina
}

El Arq. Mauro García Santa Cruz es Arquitecto FAU UNLP, 2014. Secretario Técnico del Laboratorio de Arquitectura y Hábitat Sustentable FAU UNLP desde 2010. Censista en el Censo Nacional de Infraestructura Escolar, relevamientos de campo y procesamiento de datos (CeNIE09 - FAU UNLP). Asesor en la consultora grgarcía\&asoc en temas de arquitectura sustentable y conservación preventiva. Participó de la Puesta en valor de la capilla de la Estancia Los Álamos, que recibió el Premio a la mejor Intervención 2003 SCA CICOP, del Mapeo de desajustes para la intervención de las capillas de los Hospitales Borda y Moyano y del proyecto para el Museo Histórico del Partido de Pinamar. Participa en proyectos de investigación con financiamiento de ANPCyT, CONICET y UNLP sobre arquitectura sustentable y condiciones ambientales en edificios para la cultura desde 2007. Becario Doctoral CONICET desde 2014, siendo el tema de investigación el “Desarrollo de un protocolo para evaluación y certificación de la sustentabilidad en edificios para la cultura". Alumno del Doctorado en Arquitectura y Urbanismo, Facultad de Arquitectura y Urbanismo, UNLP. Participó en más de 35 congresos, encuentros y jornadas sobre temas de arquitectura sustentable, conservación del patrimonio y conservación preventiva. Autor y coautor de artículos publicados en revistas científicas con referato, capítulos de libros y trabajos publicados en las actas de eventos científicos. Editor Técnico y co-autor del libro "Cuadernos de Arquitectura Sustentable, Artículos Seleccionados, 2011", compilado por Jorge D. Czajkowski y Analía F. Gómez ISBN 978-950-34-0800-1.Miembro del Comité Organizador del “I Encuentro Nacional sobre Ciudad, Arquitectura y Construcción Sustentable"del "Seminario Técnico ASHRAE y el LAyHS FAU UNLP y del Seminario"Reflexiones sobre las transiciones energéticas metropolitanas" organizado por el LAyHS FAU UNLP y el Centro de Estudios Urbanos y Regionales CEUR CONICET.

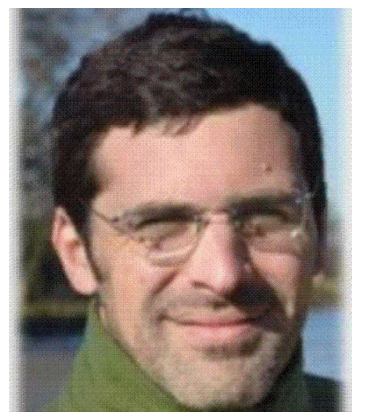

\title{
Dr. Mario Nazareno Saparrat
}

masaparrat@yahoo.com.ar

Instituto de Fisiología Vegetal. CONICET-UNLP de La Plata. Buenos Aires, Argentina

El Dr. Mario Saparrat, Investigador Adjunto CONICET en el INFIVE, Profesor Adjunto UNLP en la Cátedras: Microbiología agrícola (Facultad de Ciencias Agrarias y Forestales, UNLP) y Botánica Sistemática I (Facultad de Ciencias Naturales y Museo, UNLP), Vicepresidente de la Asociación Micológica Carlos Spegazzini. Desarrolla investigación en el campo de la fisiología de hongos y su rol en la transformación de materiales orgánicos y los pigmentos de los hongos, específicamente melaninas. Participa del Programa de Incentivos a los Docentes-Investigadores, Secretaría de Política Universitaria del Ministerio de Educación de la Nación en la Categoría III. Posee financiamiento para su investigación PICT como Investigador responsable (grupo en formación). Ha realizado diversas estancias y pasantías posdoctorales en el exterior. Ha recibido 4 distinciones. Ha sido docente expositor en numerosos cursos de postgrado. Ha sido coordinador y expositor en numerosos y diversos eventos científicos. Es director de varios becarios y tesistas en diferentes centros del país. Evaluador de Comisiones Científicas, Tesis y concursos docentes. Tiene en su haber numerosos arbitrajes de publicaciones científicas nacionales e internacionales y es Editor de sección sobre Plantas avasculares en la Revista Nacional "Darwiniana Nueva Serie". Ha participado en numerosos congresos y eventos científicos y presenta un alto número de publicaciones como primer autor, autor responsable (último) y en coautoría.

Artículo enviado el 14/07/2016

Artículo aceptado el 16/11/2016 